\title{
THE DIFFERENCE OF EFFECTIVITY BETWEEN MANGOSTEEN PEEL EXTRACT AND METRONIDAZOLE ON FIBROBLAST PROLIFERATION
}

\author{
Adinda Nur Atiqah*, Adisty Restu Poetri ${ }^{\star *}$, Moh. Husnun Niam ${ }^{\star \star \star}$
}

${ }^{\star}$ Program Pendidikan Dokter Gigi Fakultas Kedokteran Gigi Universitas Islam Sultan Agung

**Departemen Periodonsia Fakultas Kedokteran Gigi Universitas Islam Sultan Agung

${ }^{* \star \star}$ Departemen IImu Kesehatan Gigi Masyarakat Fakultas Kedokteran Gigi Universitas Islam Sultan Agung

Correspondence : adistyrestupoetri@unissula.ac.id

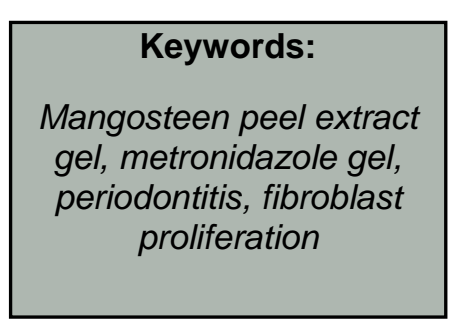

\section{PENDAHULUAN}

Kesehatan rongga mulut masih menjadi perhatian utama karena berdasar Riset Kesehatan Dasar (RISKESDAS) 2018 prevalensi penyakit periodontal cukup tinggi ${ }^{1}$. Penyakit periodontal ialah suatu kondisi inflamasi kronis di jaringan periodontal, baik jaringan lunak ataupun jaringan keras misalnya ligamen periodontal, sementum, gingiva, serta tulang alveolar ${ }^{2,3}$. Secara umum, penyebab terjadinya adalah kolonisasi dan pertumbuhan bakteri seperti Porphyromonas gingivalis, Prevotella intermedia, Actinobacillus actinomycetemnomitans yang terdapat pada plak gigi dan kemudian menyebabkan munculnya cardinal symptoms sebagai tanda terjadinya inflamasi ${ }^{4,5}$. Salah satu kondisi inflamasi yang

\begin{abstract}
ABSTRACT
Background: The disease of the oral cavity is quite common in the society is periodontitis. The main cause of this condition is a certain bacterial infection xanthones and flavonoids which are known to be antibacterial and anti-
inflammatory. This research aims to specify the differences in the effectiveness xanthones and flavonoids which are known to be antibacterial and anti-
inflammatory. This research aims to specify the differences in the effectiveness on fibroblast proliferation. Method: This is a laboratory experimental design using post-test only design consisted of 50\% mangosteen peel extract gel group, $75 \%$ mangosteen peel extract gel group, $25 \%$ metronidazole gel group and metronidazole plus gel
group. This research used male Wistar rats induced periodontitis by ligation for 7 days as samples. Results: The results reveal that there was a differences in effectiveness One Way ANOVA with a significance of $0.000(p<0.05)$.

Conclusion: It can be concluded that there was differences in the effectiveness of mangosteen peel extract gel and metronidazole gel as anti-inflammatory on proliferation of fibroblast in periodontitis healing process. of anti-inflammatory between mangosteen peel extract and metronidazole gel
\end{abstract}

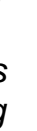

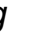


Terapi tambahan pada perawatan periodontitis sebenarnya dapat juga berasal dari bahan dasar alami, salah satunya adalah kulit buah manggis ${ }^{10}$. Di lingkungan masyarakat, kulit buah manggis tergolong sebagai limbah yang pemanfaatannya masih belum maksimal. Selain itu, pemanfaatan kulit buah manggis pada bidang kesehatan khususnya kesehatan gigi dan mulut masih terbatas walaupun kandungan senyawanya memiliki manfaat yang cukup besar ${ }^{11}$. Kulit buah manggis memiliki kandungan antibakteri maupun antiinflamasi berupa Xanthone, Thanine, Saphonine, Alkaloid, dan Flavonoid. Daya antibakteri dan antiinflamasi yang dimiliki oleh kulit buah manggis diketahui dapat mempercepat waktu berlangsungnya fase inflamasi sehingga fase proliferasi dapat segera terjadi ${ }^{10}$. Pada fase proliferasi bertujuan membentuk keseimbangan antara pembentukan jaringan granulasi dan regenerasi jaringan salah satunya melalui proses proliferasi fibroblas ${ }^{11}$. Berdasarkan penelitian terdahulu menunjukkan bahwa ekstrak kulit buah manggis dapat menginduksi migrasi fibroblas lebih baik daripada povidone iodine ${ }^{12}$, serta efektif sebagai antibakteri pada konsentrasi 50\% dan berbanding lurus dengan kenaikan konsentrasi ${ }^{13}$.

Berdasarkan teori ilmiah tersebut maka peneliti tertarik memperluas pemanfaatan kulit buah manggis dalam bidang kesehatan gigi dan mulut dan bertujuan untuk mengetahui perbedaan efektivitas antiinflamasi ekstrak kulit buah manggis dan metronidazole terhadap proliferasi fibroblas.

\section{METODE PENELITIAN}

Ethical clearance penelitian ini didapatkan dari Komisi Etik Penelitian Kesehatan Fakultas Kedokteran Gigi Unissula No.248/B.1-KEPK/SAFKG/XII/2020. Penelitian berikut berjenis eksperimental laboratoris menggunakan post test only design. Terdapat 4 kelompok perlakuan diantaranya kelompok gel ekstrak kulit buah manggis 50\%, gel ekstrak kulit buah manggis $75 \%$, gel metronidazole $25 \%$, dan gel metronidazole plus. Sampel penelitian diambil pada ligamen periodontal tikus Wistar yang diinduksi periodontitis dan telah diberi perlakuan selama 7 hari sebanyak 24 sampel.

Alat dan bahan yang dipergunakan pada penelitian berikut terbagi atas sejumlah bagian dalam melakukan beberapa proses seperti ekstraksi dan pembuatan gel ekstrak kulit buah mangggis, proses pemeliharaan dan induksi periodontitis pada hewan coba, proses pemberian perlakuan, proses pengambilan jaringan dan pewarnaan, serta proses pengamatan hasil proliferasi fibroblas.

Proses ekstraksi dan pembuatan gel ekstrak kulit buah manggis diawali dengan proses pengeringan dan penggilingan hingga menjadi serbuk yang dilanjutkan dengan maserasi menggunakan pelarut etanol 95\% untuk proses ekstraksi. Hasil ekstraksi kemudian dilakukan penyaringan, penguapan, dan pencampuran dengan basis gel hingga didapatkan konsentrasi $50 \%$ dan $75 \%$. Basis gel sebelumnya dibuat dengan pencampuran dari CMC, aquades, TEA, propylene, dan nipagin. Proses ekstraksi dan pembuatan gel dijalankan di Laboratorium Kimia Fakultas Kedokteran Universitas Islam Sultan Agung.

Hewan coba dilakukan pemeliharaan, induksi periodontitis, dan perlakuan di Laboratorium Hewan Coba Fakultas Kedokteran Unissula. Pada penelitian ini digunakan 12 tikus Wistar jantan yang diadaptasikan terlebih dahulu selama 7 hari kemudian diinduksi periodontitis pada insisivus rahang atas dan rahang bawah. Induksi periodontitis menggunakan silk ligature ukuran 3,0 di sekeliling insisivus rahang atas dan bawah kemudian sedikit ditekan hingga masuk ke 
subgingiva dan didiamkan sekitar 7 hari hingga muncul tanda-tanda periodontitis. Tanda periodontitis yang diamati berupa kemerahan, resesi gingiva, pembengkakan, dan pembentukan poket.

Setelah terjadi periodontitis, hewan coba diberi perlakuan tiga kali sehari sesuai kelompoknya. Aplikasi gel ekstrak kulit buah manggis $50 \%$, gel ekstrak kulit buah manggis $75 \%$, gel metronidazole $25 \%$, dan gel metronidazole plus menggunakan microbrush terlebih dahulu di area sekitar poket kemudian didorong ke sekeliling poket menggunakan bantuan instrumen seperti probe.

Pengambilan jaringan dilakukan pada hari ke-7 sebagai puncak dari fase proliferasi. Jaringan difiksasi terlebih dahulu dengan buffered formalin 10\% selama 24 jam, lalu didekalsifikasi mempergunakan EDTA $10 \%$. Setelah lunak, ligamen periodontal ditanam dalam parafin serta dipotong dengan ketebalan $5 \mu \mathrm{m}$ guna dilakukan pewarnaan dengan Hematoxylin Eosin (HE). Selanjutnya, proliferasi fibroblas dihitung menggunakan mikroskop dengan perbesaran 400 kali pada tiga lapang pandang berbeda dan dihitung rata-ratanya.

\section{HASIL PENELITIAN}

Hasil penelitian mengenai proliferasi fibroblas yang diberi perlakuan gel ekstrak kulit buah manggis $50 \%$, gel ekstrak kulit buah manggis $75 \%$, gel metronidazole $25 \%$, dan gel

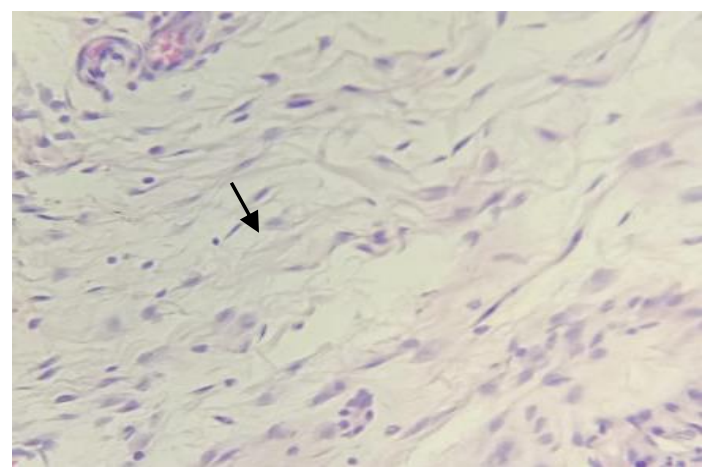

metronidazole plus menunjukkan gambaran histopatologi sebagai berikut :

Gambar 1. Sel Fibroblas Pada Kelompok Gel Metronidazole Plus

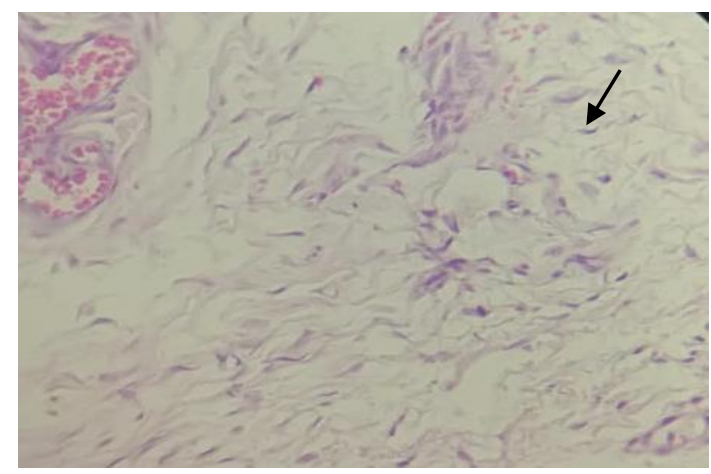

Gambar 2. Sel Fibroblas Pada Kelompok Gel Metronidazole 25\%

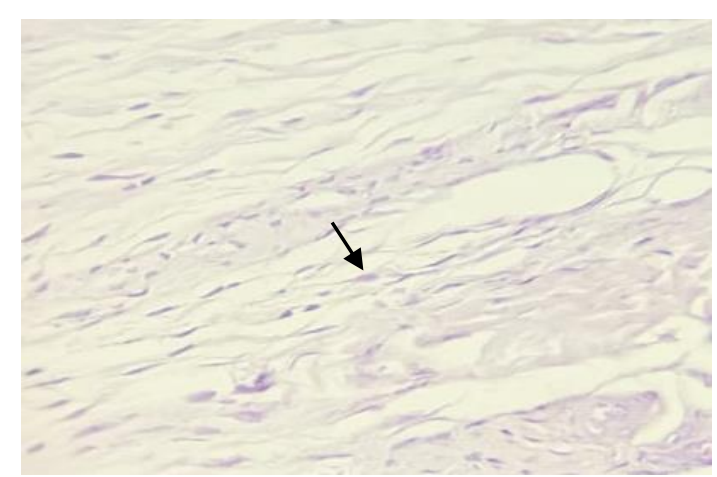

Gambar 3. Sel Fibroblas Pada Kelompok Gel Ekstrak Kulit Buah Manggis 75\%

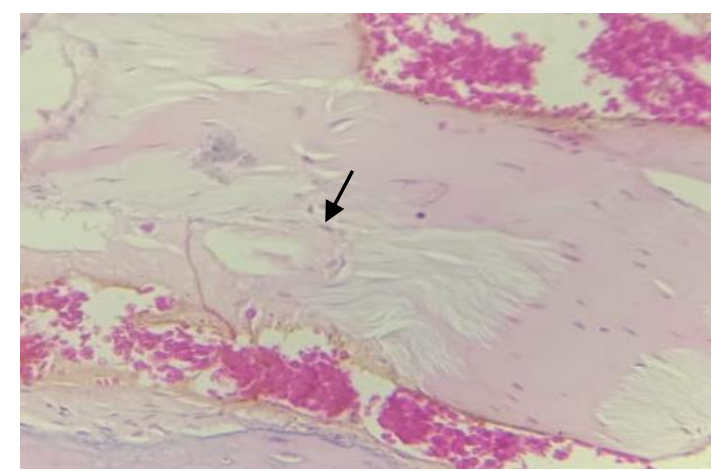

Gambar 4. Sel Fibroblas Pada Kelompok Gel Ekstrak Kulit Buah Manggis 50\%

Berdasar gambaran tersebut, terlihat proliferasi fibroblas yang tertinggi adalah pada kelompok gel metronidazole plus, kemudian kelompok gel metronidazole $25 \%$, selanjutnya kelompok gel ekstrak kulit buah manggis $75 \%$, dan 
yang paling rendah yakni kelompok gel ekstrak kulit buah manggis $50 \%$.

Data dari hasil penelitian yang diperoleh kemudian dilanjutkan uji normalitas serta uji homogenitas. Hasil normalitas dengan ShapiroWilk Test di seluruh kelompok diperoleh nilai signifikansi $(p>0,05)$ dan hasil homogenitas dengan Levene Test diperoleh nilai signifikansi $(p>0,05)$ memperlihatkan distribusi data normal serta homogen sehingga syarat uji parametrik dengan One Way ANOVA terpenuhi.

Setelah memenuhi syarat uji parametrik, dilanjutkan dengan uji hipotesis One Way ANOVA sebagai uji komparatif variabel numerik lebih dari dua kelompok yang hasil ujinya tertera di tabel berikut :

Tabel 1. Uji One Way ANOVA

\begin{tabular}{ll}
\hline & Sig. \\
\hline Between Groups & .000 \\
\hline
\end{tabular}

Terlihat pada tabel di atas, hasil nilai signifikansi $0,000 \quad(p<0,05)$, maka bisa ditarik kesimpulan terdapat perbedaan yang signifikan antara kelompok gel ekstrak kulit buah manggis $50 \%$, gel ekstrak kulit buah manggis $75 \%$, gel metronidazole 25\%, dan gel metronidazole plus. Setelah diketahui terdapat perbedaan signifikan pada uji One Way ANOVA, lalu diuji post hoc Bonferroni guna mengetahui perbedaan signifikan antar kelompok perlakuan seperti ditunjukkan di tabel 2 berikut ini :

Tabel 2. Hasil Uji Post Hoc Bonferroni

\begin{tabular}{ccccc}
\hline & Gel & Gel & & \\
Kelompo & ak & Ekstr & & \\
k & Kulit & Kulit & Mel & Gel \\
Perlakua & Buah & Buah & azole & Metronid \\
n & Man & Man & $25 \%$ & Plus \\
& ggis & ggis & & \\
& $50 \%$ & $75 \%$ & & \\
\hline
\end{tabular}

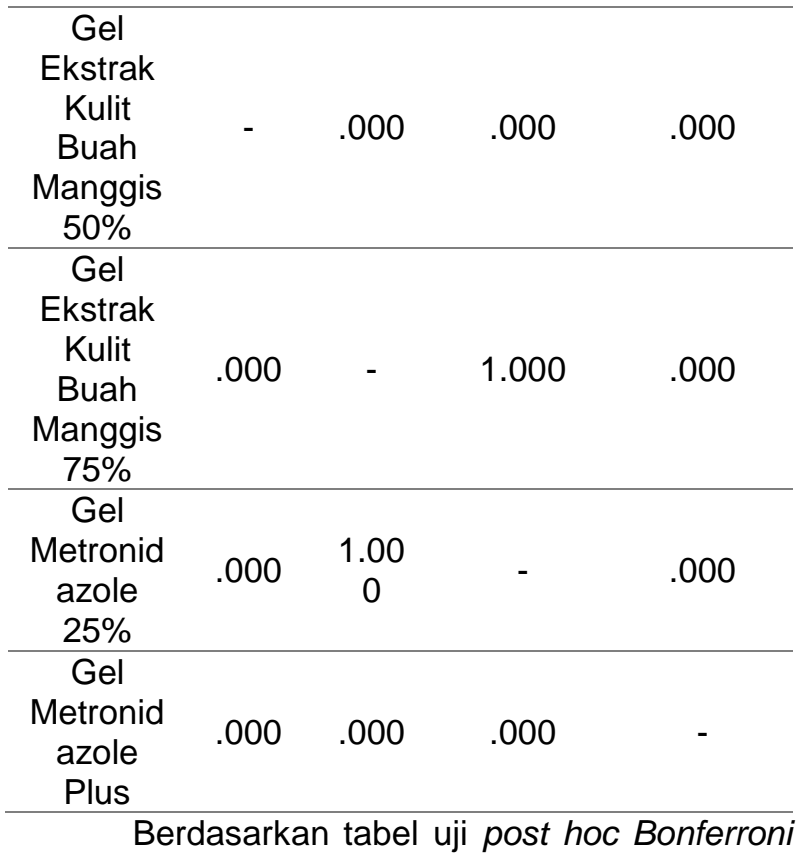

di atas, bisa disimpulkan bahwa ada perbedaan yang signifikan antar kelompok perlakuan kecuali antara kelompok gel ekstrak kulit buah manggis $75 \%$ dengan gel metronidazole $25 \%$ tidak menunjukkan perbedaan yang signifikan.

\section{DISKUSI}

Berdasarkan hasil pengamatan yang didapat, kelompok gel ekstrak kulit buah manggis 75\% lebih efektif daripada kelompok gel ekstrak kulit buah manggis $50 \%$ terhadap proliferasi fibroblas.

Hal ini sesuai dengan penelitian terdahulu bahwa efektivitas ekstrak kulit buah manggis berbanding lurus dengan konsentrasinya, karena semakin tinggi jumlah konsentrasinya maka kandungan senyawanya semakin banyak ${ }^{10,14}$. Kandungan yang terdapat di dalamnya berupa xanthone, saphonine, dan flavonoid yang dapat bekerja sebagai antiinflamasi dengan menghambat kerja dari enzim cyclooxygenase dan lipoxygenase. Adanya hambatan kerja pada enzim tersebut menyebabkan pelepasan dari mediator inflamasi seperti prostaglandin, prostasiklin, tromboksan, dan leukotrin berkurang sehingga mempengaruhi waktu 
dari proses inflamasi yang semakin cepat yang ditandai dengan peningkatan proliferasi fibroblas ${ }^{10}$. Selain itu, terdapat juga kandungan catechin yang menekan pelepasan prostaglandin pada jalur asam arakhidonat. Penekanan ini dapat menyebabkan berkurangnya cardinal symptoms, sehingga migrasi sel radang akan menurun serta mempercepat fase inflamasi serta memulai fase proliferasi ${ }^{15}$.

Pada tabel 1 dan 2 memperlihatkan bahwa gel metronidazole plus paling efektif sebagai antiinflamasi dalam memicu terjadinya proliferasi fibroblas. Hal ini disebabkan oleh adanya kandungan tambahan pada metronidazole plus yaitu asam mefenamat sebagai antiinflamasi, sehingga dapat memaksimalkan kerja dari obat ini sebagai antibakteri dan antiinflamasi. Daya antiinflamasi didapatkan melalui penghambatan enzim cyclooxygenase untuk mensintesis mediator inflamasi sehingga proses inflamasi akan segera terhenti dan memasuki fase selanjutnya ${ }^{8,16}$. Di samping itu, aktivitas inflamasinya juga dapat merangsang makrofag $\mathrm{M} 2$ dalam menghasilkan sitokin dan growth factor seperti IL-4 dan TGF- $\beta$ yang dapat menginduksi fibroblas untuk berproliferasi setelah fase inflamasi terhenti ${ }^{11,17}$.

Hasil uji post hoc juga memperlihatkan hasil bahwa kelompok gel ekstrak kulit buah manggis $75 \%$ dan kelompok gel metronidazole $25 \%$ sama efektifnya dalam memicu proliferasi fibroblas pada proses penyembuhan periodontitis. Hal ini dikarenakan pada kulit buah manggis juga terdapat efek antibakteri dari kandungan flavonoid, saphonine, dan alkaloid. Kandungan flavonoid yang bersifat asam memiliki mekanisme dengan cara masuk ke dalam sel serta mengikat protein membran sel sehingga mengakibatkan struktur protein rusak serta gangguan pada permeabilitas sel yang berdampak kepada hilangnya makromolekul serta ion dari sel, sehingga sel kehilangan bentuk bahkan terjadi lisis. Kandungan saphonine bekerja dengan mengganggu permeabilitas membran sel sehingga dinding sel tidak selektif terhadap zat-zat di luar sel yang dapat menghambat pertumbuhan atau membunuh bakteri tersebut ${ }^{13}$. Kandungan lainnya ialah alkaloid yang dapat menghambat sintesis DNA bakteri sehingga menyebabkan fungsi sel terganggu dan diikuti dengan kematian sel bakteri ${ }^{18}$.

Kandungan alkaloid pada kulit buah manggis yang telah dibahas sebelumnya memiliki mekanisme yang hampir sama dengan antibiotik metronidazole $25 \%$ sebagai antibakteri. Daya antibakteri dari metronidazole $25 \%$ bekerja melalui interaksi antara metronidazole dengan molekul DNA bakteri yang mengakibatkan hilangnya struktur helix DNA serta putusnya untai DNA sehingga terjadi hambatan sintesis DNA serta matinya sel bakteri1,9. Metronidazole dan ekstrak kulit buah manggis dapat mengeliminasi bakteri penyebab periodontitis sebagai upaya yang mendukung fase inflamasi untuk mencegah terjadinya kolonisasi maupun infeksi yang lebih parah, sehingga inflamasi dapat terjadi dalam waktu singkat dan dilanjutkan dengan regenerasi jaringan salah satunya melalui proses proliferasi fibroblas ${ }^{8}$.

Berdasarkan pembahasan yang telah dijabarkan sebelumnya, gel ekstrak kulit buah manggis dapat direkomendasikan sebagai salah satu sediaan dari bahan alami yang bisa dipergunakan selaku terapi tambahan pada perawatan periodontitis karena beberapa kandungan di dalamnya dapat bekerja sebagai antiinflamasi dan antibakteri. Disisi lain, dengan penelitian berikut bisa menambah referensi bahwa buah manggis tidak sebatas diambil daging dari buahnya, namun kulit buah manggis juga dapat dimanfaatkan sebagai terapi tambahan khususnya bidang kedokteran gigi dalam sediaan gel untuk terapi periodontitis ${ }^{13}$. 


\section{KESIMPULAN}

Mengacu pada penelitian yang sudah dijalankan, bisa ditarik suatu kesimpulan bahwa terdapat perbedaan efektivitas antiinflamasi antar kelompok perlakuan dalam memicu peningkatan proliferasi fibroblas kecuali antara kelompok gel ekstrak kulit buah manggis $75 \%$ dengan gel metronidazole $25 \%$.

\section{UCAPAN TERIMAKASIH}

Peneliti mengucapkan terima kasih kepada berbagai pihak yang telah membantu penelitian, khususnya kepada institusi yaitu Fakultas Kedokteran Gigi Universitas Islam Sultan Agung.

\section{DAFTAR PUSTAKA}

1. Tedjasulaksana R. Metronidasol sebagai salah satu obat pilihan untuk periodontitis marginalis. J Kesehat Gigi. 2016;4:19-23.

2. Vargas SAI, llyina A, Segura CEP, Silva BY, L MG. Etiology and microbiology of periodontal diseases: $A$ review. African J Microbiol Res. 2015;9(48):2300-6.

3. Newman M, Takei H, Klokkevold P, Carranza F. Carranza Clinical Periodontology 13th ed 2. 2019. 27-33 p.

4. Murakami S. Dental plaque-induced gingival conditions. J Clin Periodontol. 2018;45(February 2017):S17-27.

5. Siregar I, Supardan I, Sulistijarso N. Pengaruh Pasta Ekstrak Daun Sukun (ArtocarpusAltilis) terhadap Perubahan Sel Fibroblas dan Jaringan Kolagen pada Periodontitis. J Ris Kesehat. 2015;4(3):786-92.

6. Abdurrohman MMS, Putranto RR. Metronidazole Gel Effect on Rats With Bacteria-Induced Periodontitis. ODONTO Dent J. 2020;7(1):48.

7. Quamilla N. Stres Dan Kejadian Periodontitis (Kajian Literatur). J Syiah Kuala Dent Soc. 2016;1(2):161-8.

8. Haris M, Panickal DM. Role of Metronidazole as a Local Drug Delivery in the Treatment of Periodontitis:A Review. Int J Oral Heal Med Res. 2017;3(July):141-5.

9. Wijayanto R, Herawati D, Sudibyo. Perbedaan
Efektivitas Topikal Gel Asam Hialuronat Dan Gel Metronidazol Terhadap Penyembuhan Jaringan Periodontal Setelah Kuretase Pada Periodontitis Kronis. J Ked Gi [Internet]. 2014;5(3):307-11.

10. Putri K, Darsono L, Mandalas H. Anti-Inflammatory Properties of Mangosteen Peel Extract on The Mice Gingival Inflammation Healing Process. Padjadjaran J Dent. 2017;29(3):190-5.

11. Wathoni N, Putri NA, Cahyanto A, Muchtaridi M. Pemanfaatan Manggis Sebagai Sediaan Antiseptik dalam Upaya Peningkatan Kesehatan Masyarakat di Desa Sayang, Jatinangor, Sumedang. Maj Farmasetika. 2020;5(2):57.

12. Primadina N, Basori A, Perdanakusuma DS. Proses Penyembuhan Luka Ditinjau dari Aspek Mekanisme Seluler dan Molekuler. Qanun Med - Med J Fac Med Muhammadiyah Surabaya. 2019;3(1):31.

13. Wisuitiprot W, Wisutthathum S, Pitiporn S, Wisuitiprot V, Kwankhao P, Waranuch N. Effect of Garcinia Mangostana Linn Fruit Peel Ethanolic Extract on Fibroblast Cell Migration. Biomed J Sci Tech Res. 2019;19(3).

14. Widayat MM, Purwanto, Shita A, Dewi P. Daya Antibakteri Infusa Kulit Manggis ( Garcinia mangostana $L$ ) terhadap Streptococcus mutans. eJurnal Pustaka Kesehat. 2016;4(3):514-8.

15. Azzahra H, Pujiastuti P, Purwanto. Potensi Ekstrak Kulit Buah Manggis ( Garcinia mangostana L .) Buatan Pabrik Terhadap Peningkatan Aktivitas Mikrobisidal Sel Neutrofil yang Dipapar Streptococcus mutans. e-Journal Pustaka Kesehat. 2014;2(1):161-6.

16. Dwintanandi C, Nahzi MYI, Raharja SD. Pengaruh Ekstrak Kulit Manggis (Garcinia mangostana Linn.) Terhadap Jumlah Makrofag Pada Inflamasi Pulpa. J Kedokt Gigi. 2016;I(2):151-7.

17. Mendes CL, Assis $\mathrm{P}$ de, Annibal H, Oliveira LJR de, Albuquerque MS de, Soares $M$ de $L$, et al. Metronidazole and amoxicillin association in aggressive periodontitis: A systematic review and meta-analysis. Saudi Dent J. 2020;32(6):269-75.

18. Laut $M$, Ndaong $N$, Utami $T$, Junersi $M$, Bria Seran Y, Farmakologi dan Toksikologi FKH Undana JI Adisucipto B, et al. EFEKTIVITAS PEMBERIAN SALEP EKSTRAK ETANOL DAUN ANTINGANTING (Acalypha indica Linn.) TERHADAP KESEMBUHAN LUKA INSISI PADA MENCIT (Mus musculus) (The Effectiveness of Topical Ointment Containing Ethanolic Extract of Acalypha Indica Leaves on Wound Healing. J Kaji Vet. 2019;7(1):111.

19. Sriyono RAN, Andriani I. Daya Antibakteri Ekstrak Etanol Kulit Manggis (Garcinia Mangostana Linn.) Ter- hadap Bakteri Porphyromonas Gingivalis Antibacterial. Indones Dent J. 2013;2(2):76-82. 